\title{
Proton pump inhibitors increase the overall risk of developing bacterial infections in patients with cirrhosis
}

\author{
IIIce B LÁZARO-PACHEC ${ }^{1}$, Alfredo I SERVÍN-CAAMAÑN ${ }^{2}$, José L PÉREZ-HERNÁNDEZ ${ }^{3}$, \\ Gabriela ROJAS-LOUREIR0 ${ }^{1}$, Luis SERVÍN-ABAD ${ }^{4}$ and Fátima HIGUERA-DE LA TIJERA ${ }^{3}$
}

Received 23/7/2017

Accepted 28/11/2017

\begin{abstract}
Background - Acid suppression has been associated with adverse events; such as, enteric infections. Proton pump inhibitors (PPI) are frequently prescribed in patients with cirrhosis, but is unclear if PPI are associated with the development of bacterial infections in these patients. Objective - To assess the impact of PPI intake on the development of bacterial, viral and fungal infections in patients with cirrhosis. Methods - An observational, retrospective, historic cohort study. The exposed cohort included patients with cirrhosis with chronic use of PPI. The non-exposed cohort had not been using PPI. The follow-up period was 3 years, searching in the medical records for any events of bacterial infection confirmed by bacteriological culture. Results - One hundred and thirteen patients met the selection criteria, 44 (39\%) had chronic use of PPI; of them, 28 (63.6\%) patients had not a clear clinical indication to justify the prescription of PPI. Twenty four $(21.2 \%)$ patients developed bacterial infections during the follow-up period. In the univariate analysis, decompensated cirrhosis (Child B/C), presence of ascites, history of variceal bleeding, and chronic consumption of PPI were risk factors related to the development of infections. But, in the adjusted multivariate analysis only the chronic use of PPI was associated with development of infections ( $\mathrm{RR}=3.6 ; 95 \% \mathrm{CI}=1.1-12.3 ; P=0.04)$. Conclusion - There is an over-prescription of PPI without a justified clinical indication. The long-term consumption of PPI in patients with cirrhosis is associated with the development of bacterial infections; therefore these drugs must be carefully prescribed in this specific population.
\end{abstract}

HEADINGS - Proton pump inhibitors, adverse effects. Inappropriate prescribing. Liver cirrhosis. Risk assessment.

\section{INTRODUCTION}

Patients with cirrhosis, particularly those with decompensated disease, are at risk of developing serious bacterial infections due to several factors ${ }^{(1,2)}$; such as, portal hypertension ${ }^{(3)}$, immunologic impairment ${ }^{(4)}$, quantitative and qualitative changes in gut microbiota, intestinal dismotility ${ }^{(5)}$, small intestinal bacterial overgrowth ${ }^{(6,7)}$.

The gastric acidity is an important host defense barrier; therefore, acid suppression has been associated with adverse events; such as, enteric infections $s^{(8,9)}$, pulmonary infections ${ }^{(10,11)}$, development of bacterial intestinal overgrowth and bacterial translocation ${ }^{(7)}$. Proton pump inhibitors (PPI) are frequently prescribed in patients with cirrhosis, but at least two studies have reported a high prevalence of patients taking acid-suppressive therapy without a clear indication $^{(12,13)}$. The safety regarding PPI in patients with cirrhosis has not been established.

Several studies have observed an association between PPI intake and the development of spontaneous bacterial peritonitis (SBP) in patients with cirrhosis ${ }^{(3,12-19)}$. On the other hand, this association was not observed in all studies ${ }^{(20,21)}$. Several limitations related to the study design, as well as, the potential confounding factors substantially limit conclusions from these previous studies.

The aim of this study was to assess the impact of PPI intake on the development of bacterial, viral and fungal infections in patients with cirrhosis.

\section{Study design}

\section{METHODS}

We designed an observational, retrospective, historic cohort study. The study was performed at The Liver Clinic from a tertiary health-care center. The study was reviewed and approved by the Hospital General de México, Dr. Eduardo Liceaga Institutional Review Board.

\section{Selection criteria}

The exposed cohort included patients with cirrhosis who had history of chronic PPI use. Chronic PPI intake was defined as patients who had history of taking PPI, at least for 1 year, for the last year, and at least three times per week, and at a minimum dose of $20 \mathrm{mg} /$ day. This cohort was compared with another non-exposed

Declared conflict of interest of all authors: Fátima Higuera-de la Tijera has received fees for serving as a speaker for Laboratorios Liomont. The other authors have not conflict of interest to declare. None of the other researchers involved in this study have received fees for serving as a speaker, consultant or as advisory board member for any organization.

Disclosure of funding: no funding received

1 Gastroenterology and Hepatology Department, Hospital General de México Dr. Eduardo Liceaga, Mexico City, Mexico; ${ }^{2}$ Internal Medicine Department, Hospital General de México Dr. Eduardo Liceaga, Mexico City, Mexico; ${ }^{3}$ The Liver Clinic's Research Group from Gastroenterology and Hepatology Department, Hospital General de México Dr. Eduardo Liceaga, Mexico City, Mexico; ${ }^{4}$ Gastroenterology Department, Lakeland Regional Medical Center, United States of America.

Correspondence: Fátima Higuera-de la Tijera. Gastroenterology and Hepatology Department, Hospital General de México, Dr. Eduardo Liceaga. Address: Dr. Balmis 148 Mexico City, 06720. E-mail: fatimahiguera@yahoo.com.mx 
cohort to PPI. We collected information about the development of ascites, variceal bleeding, episodes of hepatic encephalopathy, bacterial, viral and fungal infections, Child-Pugh (Child) score. Also we searched if the prescription of PPI had or not a clear clinical indication to justify it. The start point of time selected to initiate the follow-up was the date of diagnosis of cirrhosis for the non-exposed cohort, and also for the exposed-cohort but in these patients we also considered the date when each patient started taking PPI medication. The follow-up was for a period of 3 years, searching in the medical records specifically the occurrence of any bacterial infection confirmed by bacteriological culture.

We excluded patients with hepatocellular carcinoma, concomitant comorbidities such as diabetes, chronic renal disease, with active alcohol intake during the follow-up period, and patients co-infected with human immunodeficiency virus.

All study participants, or their legal guardian, provided informed verbal consent prior to use your medical record data.

\section{Statistical analysis}

To summarize numeric variables, we used mean and standard deviation in case of parametric distribution, or median and range in case of non-parametric distribution. To compare between cohorts, univariate analysis was performed through $t$ Student's test or Mann-Whitney's U test, chi square test or exact Fisher's test respectively. All those significant variables in the univariate analysis were considered for the multivariate analysis; this was performed using the Cox proportional hazards model. A $P$ value $\leq 0.05$ was considered statistically significant. Statistical packages SPSS version 19.0 (IBM, New York, USA) and Epidat 3.1 (Galicia, Spain) were used.

\section{RESULTS}

In the Liver Clinic's database we found a total of 6123 medical records. We included 113 patients who met the selection criteria, of them, $44(39 \%)$ had chronic PPI use, and $69(61 \%)$ had not. In the group with chronic PPI intake, $34(72 \%)$ were taking a dose of $20 \mathrm{mg} /$ day, and $10(28 \%)$ were taking a dose of $40 \mathrm{mg} /$ day. Sixteen $(36.4 \%)$ of these patients had a clear clinical indication that justified the chronic PPI intake: eight of them had Barrett's esophagus, four had erosive esophagitis, and three were diagnosed with dyspepsia. Twenty eight (63.6\%) patients taking PPI did not have a clear clinical indication to justify the chronic use of PPI. According to Child score, $66(58.4 \%)$ were classified as Child A, $40(35.4 \%)$ as Child B, and $7(6.2 \%)$ as Child $\mathrm{C}$.

The analysis comparing the characteristics between patients with cirrhosis with chronic PPI use and non-exposed to PPI is summarized in TABLE 1.

Of 113 patients included in this study, 24 (21.2\%) patients developed any kind of infection during the follow-up period. The infections documented in these cohorts of patients are shown in TABLE 2. In the univariate analysis searching for risk factors associated with the development of infections in all patients with cirrhosis included: decompensated cirrhosis, ascites, use of PPI, and history of variceal bleeding. Patients with decompensated cirrhosis or Child $\mathrm{B} / \mathrm{C}$ had a greater risk compared with those with compensated cirrhosis or Child A (relative risk, $\mathrm{RR}=4.8$; $95 \% \mathrm{CI}=1.8-12.8 ; P=0.002$ ). Presence of ascites was related to the development of infections compared with those without ascites $(\mathrm{RR}=5.0 ; 95 \% \mathrm{CI}=1.9-13-1 ; P=0.001)$. Patients exposed to chronic
TABLE 1. Comparison between patients with cirrhosis with chronic use of PPI and cirrhotic patients not using PPI

\begin{tabular}{|c|c|c|c|}
\hline Characteristic & $\begin{array}{c}\text { Without PPI } \\
\text { intake } \\
\mathrm{n}=69\end{array}$ & $\begin{array}{c}\text { Chronic PPI } \\
\text { intake } \\
n=44\end{array}$ & $P$ value \\
\hline \multicolumn{4}{|l|}{ Demographics } \\
\hline Age (years) & $61.7 \pm 11.3$ & $62.6 \pm 10.6$ & 0.66 \\
\hline Male gender & $30(43.5)$ & $18(40.9)$ & 0.79 \\
\hline \multicolumn{4}{|l|}{ Biochemical parameters } \\
\hline Total bilirubin, $\mathrm{mg} / \mathrm{dL}$ & $1.8 \pm 1.7$ & $1.7 \pm 1.0$ & 0.68 \\
\hline Albumin, mg/dL & $3.3 \pm 0.6$ & $3.1 \pm 0.6$ & 0.19 \\
\hline INR & $1.2 \pm 0.2$ & $1.3 \pm 0.3$ & 0.09 \\
\hline Creatinine, $\mathrm{mg} / \mathrm{dL}$ & $0.9 \pm 0.5$ & $1.0 \pm 0.3$ & 0.45 \\
\hline Sodium, mmol/L & $136.9 \pm 3.5$ & $135.6 \pm 3.1$ & 0.04 \\
\hline \multicolumn{4}{|l|}{ Hematological parameters } \\
\hline Leucocytes, cell $/ \mathrm{mm}^{3}$ & $4.9 \pm 2.3$ & $4.8 \pm 1.6$ & 0.89 \\
\hline Neutrophils, cell $/ \mathrm{mm}^{3}$ & $3.1 \pm 1.5$ & $2.9 \pm 1.3$ & 0.34 \\
\hline Platelets, cell $/ \mathrm{mm}^{3}$ & $109.3 \pm 66.5$ & $114.4 \pm 43.6$ & 0.63 \\
\hline \multicolumn{4}{|l|}{ Clinical parameters } \\
\hline Presence of ascites & $15(21.7)$ & $15(34.1)$ & 0.15 \\
\hline Etiology of cirrhosis & & & 0.09 \\
\hline Alcohol & $29(42)$ & $11(25)$ & \\
\hline Viral hepatitis & $16(23.2)$ & $11(25)$ & \\
\hline NASH & $13(18.8)$ & $7(15.9)$ & \\
\hline Autoimmune & $8(11.6)$ & $818.2)$ & \\
\hline Cryptogenic & $3(4.3)$ & $7(15.9)$ & \\
\hline Child-Pugh & & & 0.18 \\
\hline A & $41(59.4)$ & $25(56.8)$ & \\
\hline $\mathrm{B}$ & $26(37.7)$ & $14(31.8)$ & \\
\hline $\mathrm{C}$ & $2(2.9)$ & $5(11.4)$ & \\
\hline $\begin{array}{l}\text { History of variceal } \\
\text { bleeding }\end{array}$ & $22(31.9)$ & $16(36.4)$ & 0.62 \\
\hline $\begin{array}{l}\text { History of } \\
\text { encephalopathy }\end{array}$ & $17(24.6)$ & $9(20.5)$ & 0.77 \\
\hline Development of infection & $10(14.5)$ & $14(31.8)$ & 0.03 \\
\hline
\end{tabular}

INR: international normalized ratio; NASH: non-alcoholic steatohepatitis; PPI: proton pump inhibitors. Numeric variables are expressed as mean \pm standard deviation. Categorical and dichotomic variables are expressed as n (\%). A $P$ value $\leq 0.05$ was considered statistically significant.

TABLE 2. Frequency of infections developed in patients with cirrhosis according to chronic use of PPI

\begin{tabular}{lccc}
\hline Infection & $\begin{array}{c}\text { All patients } \\
\mathbf{n}=113\end{array}$ & $\begin{array}{c}\text { PPI- } \\
\text { exposed } \\
\text { cohort } \mathrm{n}=44\end{array}$ & $\begin{array}{c}\text { PPI non- } \\
\text { exposed } \\
\text { cohort } \mathrm{n}=69\end{array}$ \\
\hline Without infection & 89 & 30 & 59 \\
UTI & 8 & 2 & 6 \\
SBP & 5 & 4 & 1 \\
Pneumonia & 6 & 4 & 2 \\
Cellulitis & 2 & 2 & 0 \\
Herpes-zoster virus & 1 & 1 & 0 \\
Esophageal candidiasis & 1 & 1 & 0 \\
Periodontal abscess & 1 & 0 & 1 \\
\hline
\end{tabular}

PPI proton pump inhibitors; SBP spontaneous bacterial peritonitis; UTI urinary tract infection. 
PPI intake had greater risk of develop infections that those patients non-exposed to PPI $(\mathrm{RR}=2.8 ; 95 \% \mathrm{CI}=1.1-6.9 ; P=0.03)$. History of variceal bleeding was also associated with the development of infections during the follow up period $(\mathrm{RR}=2.6,95 \% \mathrm{CI}=1.0-6.6$; $P=0.04)$. History of hepatic encephalopathy was not associated with risk of develop infections $(\mathrm{RR}=1.2,95 \% \mathrm{CI}=0.4 .3 .3 ; P=0.79)$. See TABLE 3.

In the multivariate analysis we included all those variables statistically significant in the univariate analysis; of them, only chronic use of PPI was associated with development of infections during the follow-up period $(\mathrm{RR}=3.6 ; 95 \% \mathrm{CI}=1.1-12.3 ; P=0.04)$. See TABLE 4 and FIGURE 1.

\section{DISCUSSION}

Clinicians prescribe more frequently PPI for long-term, but commonly, there are not justified indications for its prescription $^{(22-24)}$. Even more common, patients admitted to hospital are started on PPI therapy inappropriately, and after discharge often the PPI prescription is continued indefinitely ${ }^{(19,25)}$. Similarly, in our study we confirmed that many patients $(63.6 \%)$ had not clear indication for taking PPI. Other studies have reported similar frequencies of inappropriate indication of PPI, range from $50 \%$ to $78.3 \%{ }^{(12,26)}$.

In the last few years there has been controversy about the potential adverse effects of PPI, such as infections, when are

TABLE 3. Univariate analysis to identify risk factors for development of infections in patients with cirrhosis

\begin{tabular}{|c|c|c|c|c|}
\hline Characteristic & $\begin{array}{l}\text { Without development of } \\
\text { infection } n=89\end{array}$ & $\begin{array}{l}\text { Development of } \\
\text { infection } n=24\end{array}$ & $P$ value & $\mathrm{RR}(95 \% \mathrm{CI})$ \\
\hline \multicolumn{5}{|l|}{ Cirrhosis } \\
\hline Compensated $* *$ & $59(66.2)$ & $7(29.2)$ & & \\
\hline \multicolumn{5}{|l|}{ Ascites } \\
\hline Absent & $72(80.9)$ & $11(45.8)$ & & \\
\hline \multicolumn{5}{|l|}{ Chronic use of PPI } \\
\hline Yes & $30(33.7)$ & $14(58.3)$ & 0.03 & $2.8(1.1-6.9)$ \\
\hline No & $59(66.3)$ & $10(41.7)$ & & \\
\hline \multicolumn{5}{|c|}{ History of hepatic encephalopathy } \\
\hline Yes & $20(22.5)$ & $6(25.0)$ & 0.79 & $1.2(0.4-3.3)$ \\
\hline No & $69(77.5)$ & $18(75.0)$ & & \\
\hline
\end{tabular}

* Child B or C; ** Child A. PPI: proton pump inhibitors; RR: non-adjusted relative risk. Data expressed as n (\%). A $P$ value $\leq 0.05$ was considered statistically significant.

TABLE 4. Multivariate analysis to identify risk factors for development of infections in patients with cirrhosis

\begin{tabular}{lll}
\hline Characteristic & $P$ value & HR $(95 \% \mathrm{CI})$ \\
\hline
\end{tabular}

Decompensated cirrhosis * $\quad 0.68 \quad 0.8(0.2-2.9)$

Presence of ascites

0.73

$1.3(0.3-6.2)$

Chronic use of PPI

0.04

$3.6(1.1-12.3)$

History of variceal bleeding

$$
0.21
$$

$0.5(0.2-1.4)$

* Child B or C. HR hazard ratio; PPI proton pump inhibitors. Cox proportional hazards model. A $P$ value $\leq 0.05$ was considered statistically significant.

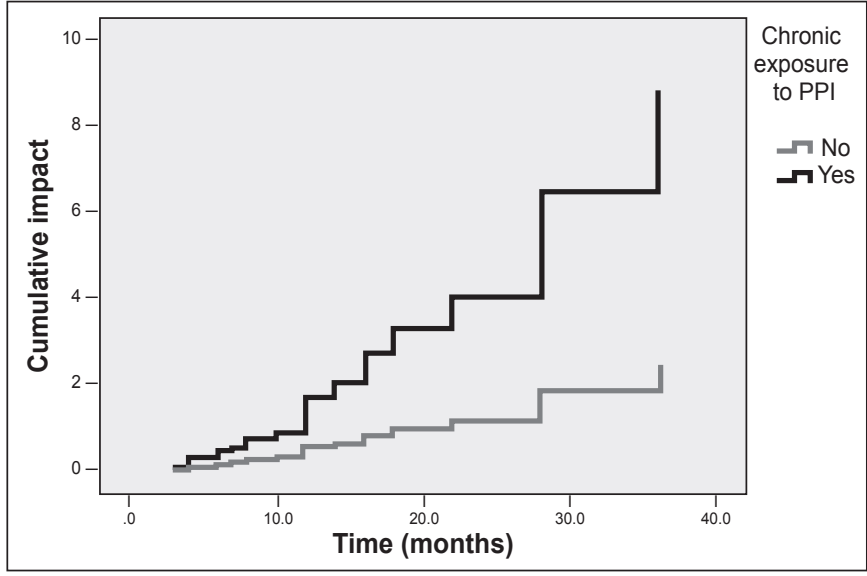

FIGURE 1. Impact of the chronic PPI intake on the development of infections in patients with cirrhosis. Graphic showing the cumulative impact for the development of infections in those with chronic use of PPI during a follow-p period of 3 years expressed in months, comparatively with a non-exposed to PPI cohort $(P=0.03)$. PPI: proton pump inhibitors. 
prescribed to patients with cirrhosis. Some studies have not found association between PPI and risk of serious infections ${ }^{(20,21)}$. In a retrospective analysis by Mandorfer $\mathrm{M}$ et al. that included a large number of patients with a high prevalence of PPI intake, there was not association between PPI intake and SBP, overall infections, nor relation with mortality ${ }^{(20)}$. Similarly, de Vos et al. did not find any association between PPI intake and risk of infections in cirrhotic patients ${ }^{(21)}$. But, in the other hand, several studies have shown a higher risk of develop SBP, other infections, other complications; like hepatic encephalopathy, or even death in those cirrhotic patients with PPI use $\mathrm{e}^{(12-18,27,28)}$. In a retrospective study by Bajaj JS et al., PPI were associated with all infections (hazard ratio, $\mathrm{HR}=1.66 ; 95 \% \mathrm{CI}=1.31-2.12$ ) and with acid suppression-related infections $(\mathrm{HR}=1.75 ; 95 \% \mathrm{CI}=1.32-2.34)^{(28)}$. Choi EJ et al., found in their study that in patients with cirrhosis and ascites the main risk factors related to the development of SBP were: Child class C, high MELD score, and PPI intake ${ }^{(15)}$. In a study by Goel GA et al. use of PPI also was associated with development of SBP, particularly in patients with advanced liver disease $^{(13)}$. Other retrospective case-control study by Bajaj JS et al. found that gastric acid suppression induced by PPI is a risk factor related to development of SBP in patients with advanced cirrhosis $^{(12)}$. The study by Ratelle $\mathrm{M}$ et al. ${ }^{(29)}$ also shown that cirrhotic patients with SBP were twice as likely to have taken PPI than patients without SBP. Our findings are in agreement with the previous studies that demonstrated an association between PPI intake and increased risk of developing infections in patients with cirrhosis, particularly, those with decompensated liver disease. In fact, our study is another study which confirms association between long-term PPI use and risk of developing infections; this is true even after adjusting the model for decompensated cirrhosis, presence of ascites, or history of variceal bleeding.

\section{CONCLUSION}

This study confirms that even in a tertiary care center, there is an over-prescription of PPI without a justified clinical indication. The long-term use of PPI in patients with cirrhosis is associated with the development of bacterial infections; therefore these drugs must be carefully prescribed in this specific population.

\section{Ethics approval}

The study was reviewed and approved by the Institutional Review Board.

\section{Informed consent}

All study participants, or their legal guardian, provided informed verbal consent prior to use your medical record data.

\section{Authors' contributions}

Lázaro-Pacheco IB, Servín-Caamaño AI, Pérez-Hernández JL, Rojas-Loureiro G collected data for the study. Servín-Abad L: wrote and translated the text. Higuera-de la Tijera F: desiged the protocol, performed the statistical analysis and wrote the text.

Lázaro-Pacheco IB, Servín-Caamaño AI, Pérez-Hernández JL, Rojas-Loureiro G, Servín-Abad L, Higuera-de la Tijera F. Inibidores de bomba protônica aumentam o risco geral de desenvolver infecções bacterianas em pacientes com cirrose. Arq Gastroenterol. 2018;55(1):28-32.

RESUMO - Contexto - A supressão de ácido tem sido associada a efeitos adversos, tais como infecções entéricas. Inibidores da bomba protônica são frequentemente prescritos em pacientes com cirrose, mas não está claro se o inibidor de bomba de próton (IBP) está associado ao desenvolvimento de infecções bacterianas nesses pacientes. Objetivo - Avaliar o impacto da ingestão de IBP no desenvolvimento de infecção bacteriana, viral e fúngica em pacientes com cirrose. Métodos - Foi realizado estudo de coorte observacional, retrospectivo, histórico. A coorte exposta incluiu pacientes com cirrose e com uso crônico de IBP. A coorte de não expostos não estava usando IBP. O período de seguimento foi de 3 anos, procurando-se nos registros médicos qualquer evento de infecção bacteriana, confirmada pela cultura bacteriológica. Resultados - Cento e treze pacientes preencheram os critérios de seleção, 44 (39\%) pacientes faziam uso crônico de IBP; deles, 28 (63,6\%) não tinham uma indicação clínica clara para justificar a prescrição de IBP. Vinte e quatro $(21,2 \%)$ pacientes desenvolveram infecções bacterianas durante o período de seguimento. Na análise univariada, cirrose descompensada (Child B/C), presença de ascite, história de hemorragia varicosa e consumo crônico de IBP foram fatores de risco relacionados ao desenvolvimento de infecções. Porém, na análise multivariada ajustada, somente o uso crônico de IBP foi associado ao desenvolvimento de infecções $(\mathrm{RR}=3,6 ; 95 \% \mathrm{CI}=1.1-12.3 ; P=0,04)$. Conclusão - Há uma prescrição excessiva de PPI sem uma indicação clínica justificada. $\mathrm{O}$ consumo de longo prazo do IBP em pacientes com cirrose é associado ao desenvolvimento de infecções bacterianas. Portanto, essas drogas devem ser cuidadosamente prescritas nesta população específica.

DESCRITORES - Inibidores da bomba de prótons, efeitos adversos. Prescrição inadequada. Cirrose hepática. Medição de risco. 


\section{REFERENCES}

1. Arvaniti V, D’Amico G, Fede G, Manousou P, Tsochatzis E, Plequezuelo M, Burroughs AK. Infections in patients with cirrhosis increase mortality four-fold and should be used in determining prognosis. Gastroenterology. 2010;139:1246-56.

2. Jalan R, Fernandez J, Wiest R, Schnabl B, Moreau R, Angeli P, Stadlbauer V, et al. Bacterial infections in cirrhosis: A position statement based on the EASL Special Conference 2013. J Hepatol. 2014;60:1310-24.

3. Gunnarsdottir SA, Sadik R, Shev S, Simren M, Sjovall H, Stotzer PO, Abrahamsson $\mathrm{H}$, et al. Small intestinal motility disturbances and bacterial overgrowth in patients with liver cirrhosis and portal hypertension. Am J Gastroenterol. 2003;98:1362-70.

4. Dirchwolf M, Podhorzer A, Marino M, Shulman C, Cartier M, Zunino M, Paz S, et al. Immune dysfunction in cirrhosis: Distinct cytokines phenotypes according to cirrhosis severity. Cytokine. 2016;77:14-25.

5. Chang CS, Chen GH, Lien HC, Yeh HZ. Small intestine dysmotility and bacterial overgrowth in cirrhotic patients with spontaneous bacterial peritonitis. Hepatology. 1998;28:1187-90

6. Bauer TM, Steinbruckner B, Brinkmann FE, Ditzen AK, Schwacha H, Aponte JJ, Pelz K, et al. Small intestinal bacterial overgrowth in patients with cirrhosis: prevalence and relation with spontaneous bacterial peritonitis. Am J Gastroenterol. 2001;96:2962-7.

7. Jun DW, Kim KT, Lee OY, Chae JD, Son BK, Kim SH, Jo YJ, et al. Association between small intestinal bacterial overgrowth and peripheral bacterial DNA in cirrhotic patients. Dig Dis Sci. 2010;55:1465-71

8. Deshpande A, Pant C, Pasupuleti V, Rolston DD, Jain A, Deshpande N, Thota $\mathrm{P}$, et al. Association between proton pump inhibitor therapy and Clostridium difficile infection in a meta-analysis. Clin Gastroenterol Hepatol. 2012;10:225-33.

9. Jump RL, Pultz MJ, Donskey CJ. Vegetative Clostridium difficile survives in room air on moist surfaces and in gastric contents with reduced acidity: a potential mechanism to explain the association between proton pump inhibitors and $\mathrm{C}$. difficile-associated diarrhea? Antimicrob. Agents Chemother. 2007;51:2883-7.

10. Laheij RJ, Sturkenboom MC, Hassing RJ, Dieleman J, Stricker BH, Jansen JB. Risk of community-acquired pneumonia and use of gastric acid-suppressive drugs. JAMA. 2004;292:1955-60.

11. Prod'hom G, Leuenberger P, Koerfer J, Blum A, Chiolero R, Schaller MD, Perre $\mathrm{C}$, et al. Nosocomial pneumonia in mechanically ventilated patients receiving antacid, ranitidine, or sucralfate as prophylaxis for stress ulcer. A randomized controlled trial. Ann Intern Med. 1994;120:653-62.

12. Bajaj JS, Ratliff SM, Heuman DM, Lapane KL. Proton pump inhibitors are associated with a high rate of serious infections in veterans with decompensated cirrhosis. Aliment Pharmacol Ther. 2012;36:866-74.

13. Goel GA, Deshpande A, Lopez R, Hall GS, van Duin D, Carey WD. Increased rate of spontaneous bacterial peritonitis among cirrhotic patients receiving pharmacologic acid suppression. Clin Gastroenterol Hepatol. 2012;10:422-7.

14. Campbell MS, Obstein K, Reddy KR, Yang YX. Association between proton pump inhibitor use and spontaneous bacterial peritonitis. Dig Dis Sci. 2008;53:394-8.
15. Choi EJ, Lee HJ, Kim KO, Lee SH, Eun JR, Jang BI, Kim TN. Association between acid suppressive therapy and spontaneous bacterial peritonitis in cirrhotic patients with ascites. Scand J Gastroenterol. 2011;46:616-20.

16. Deshpande A, Pasupuleti V, Thota P, Pant C, Mapara S, Hassan S, Rolston DD, et al. Acidsuppressive therapy is associated with spontaneous bacterial peritonitis in cirrhotic patients: a meta-analysis. J Gastroenterol Hepatol. 2013;28:235-42.

17. De Vos M, De Vroey B, Garcia BG, Roy C, Kidd F, Henrion J, Deltenre P. Role of proton pump inhibitors in the occurrence and the prognosis of spontaneous bacterial peritonitis in cirrhotic patients with ascites. Liver Int. 2013;33:1316-23.

18. Kwon JH, Koh SJ, Kim W, Jung YJ, Kim JW, Kim BG, Lee KL, et al. Mortality associated with proton pump inhibitors in cirrhotic patients with spontaneous bacterial peritonitis. J Gastroenterol. Hepatol. 2014;29:775-81.

19. Gupta R, Garg P, Kottoor R, Munoz JC, Jamal MM, Lambiase LR, Vega KJ Overuse of acid suppression therapy in hospitalized patients. South Med J. 2010;103:207-11

20. Mandorfer M, Bota S, Schwabl P, Bucsics T, Pfisterer N, Summereder C, Hagmann M, et al. Proton Pump Inhibitor Intake neither Predisposes to Spontaneous Bacterial Peritonitis or Other Infections nor Increases Mortality in Patients with Cirrhosis and Ascites. PLoS ONE. 2014;9:e110503.

21. Van Vlerken LG, Huisman EJ, van Hoek B, Renooij W, de Rooij FW, Siersema PD, van Erpecum KJ. Bacterial infections in cirrhosis: role of proton pump inhibitors and intestinal permeability. Eur J Clin Invest. 2012;42:760-7.

22. Heidelbaugh JJ, Kim AH, Chang R, Walker PC. Overutilization of proton pump inhibitors: what the clinician needs to know. Therap Adv Gastroenterol 2012;5:219-32.

23. Lanas A. We are using too many PPIs, and we need to stop: A European perspective. Am J Gastroenterol. 2016;111:1085-6.

24. Vakil N. Prescribing proton pump inhibitors: is it time to pause and rethink? Drugs. 2012;72:437-45

25. Ahrens D, Chenot JF, Behrens G, Grimmsmann T, Kochen MM. Appropriateness of treatment recommendations for PPI in hospital discharge letters. Eur J Clin Pharmacol. 2010;66:1265-71.

26. Dultz G, Piiper A, Zeuzem S, Kronenberger B, Waidmann O. Proton pump inhibitor treatment is associated with the severity of liver disease and increased mortality in patients with cirrhosis. Aliment Pharmacol Ther. 2015;41:459-66.

27. Bajaj JS, Zadvornova Y, Heuman DM, Hafeezullah M, Hoffmann RG, Sanya AJ, Saeian K. Association of proton pump inhibitor therapy with spontaneous bacterial peritonitis in cirrhotic patients with ascites. Am J Gastroenterol. 2009; 104:1130-4.

28. Dam G, Vilstrup H, Watson H, Jepsen P. Proton pump inhibitors as a risk factor for hepatic encephalopathy and spontaneous bacterial peritonitis in patients with cirrhosis with ascites. Hepatology. 2016;64:1265-72.

29. Ratelle M, Perreault S, Villeneuve JP, Tremblay L. Association between proton pump inhibitor use and spontaneous bacterial peritonitis in cirrhotic patients with ascites. Can J Gastroenterol Hepatol. 2014;28:330-4. 